\title{
Effects of Adventure Based Group Counselling on Cognitive Flexibility and Intolerance of Uncertainty Levels of Counselling Psychologists Candidates
}

\author{
Asiye Busra Sirin-Ayva, PhD \\ Counselling Psychologist \\ sensecounselling.co.uk
}

\author{
Assoc Prof Azize Nilgun Canel \\ Ataturk Education Faculty \\ Marmara University
}

\section{Background}

In recent years, many nature and outdoor based postmodern therapies have emerged. Ecotherapy, nature therapy, outdoor therapy, adventure therapy, wilderness therapy are some of them (Itin\& Mitten, 2006). The main reason behind using the nature in therapeutic environment is that nature addresses many senses of individuals. The natural environment and the multiple sensory experiences in this environment help to build the cognitive structure necessary to sustain mental development (Louv, 2005). In accordance with this idea, it is also shown that nature and activity in nature are related to health (Richardson \& Mitchell, 2010), academic success (Matsuoka, 2010), self-esteem (Rogerson at al., 2015; Wood, Sanderock, Barton, Pretty, at al., 2007, Pretty, Peacock, Sellens, \& Griffin, 2005), mood (Rogerson, at al., 2015, Wood, Pretty, Sandercock\& Barton, 2013; Barton, Griffin, Pretty, Peacock, Sellens, \& Griffin, 2005) and stress (Rogerson at al., 2015) and some other variables.

Adventure therapy, unlike other therapeutic interventions, does not take place in the therapist's or consultant's office, it often takes place in the natural environment (Beringer, \& Martin, 2003). Even if adventure therapy does not occur outdoors (e.g. natural, semi-natural or urban environment), the environment is still an important factor (Beringer, \& Martin, 2003). When participants perform physical tasks, it is often more important to enjoy the beauty of nature in rural areas than achieving these tasks (Hattie, at al., 1997).

Adventure therapy is a change oriented approach often implemented in natural environments (Gass, Gillis \& Russel, 2012); uses adventure experiences and experiential education applications together, implemented by mental health professionals (Rutko, \& Gillespie, 2013); related to cognitive, behavioural and affective changes of clients kinaesthetically and; included experiential activities and uses isomorphic metaphors and has actual risk (Gass, 1995; Newes\&Bandroff, 2004); needed experience process and participation to courage change, uses though activities; can be implemented with individuals or groups (Newes\&Bandroff, 2004); increasingly has being gained popularity (Frishman, 2006; Gass, 1995). Outdoor should be considered as an environment where rich opportunities with meaningful interactions are provided to help each participant understand how the world is experienced by themselves (Itin, 2001; Jones, Lowe, Risler, 2004; Beringer, \& Martin, 2003; Hoag, Massey, Roberts, \& Logan, 2013); life is easier with minimised distractions in those environment, and natural results are a result of nature (not adult authority figures) (Stevens at al., 2004).

In this approach, adventure offers a concrete, action-based and experimental tool for therapy (Beringer, \& Martin, 2003). According to Jacobs \& Schimmel (2012) main purpose of using movement in counselling process is to make counselling process more concrete, understandable and attractive. Thanks to the movement, the sessions become dynamic and this is most useful when working with children and adolescents (Jacobs \& Schimmel, 2012). Adventure therapy may occasionally include some physical activities such as mountain climbing, hiking, backpacking, camping, canoeing / rafting.In the process, adventure therapy uses metaphors associated with real life situations to guide participants' learning (Hans, 2000).

Generally, the psychological components of adventure activities (trust, personal development, active or perceived risk taking, etc.)and physical exercises are blended to help the participants take responsibility for their personal value, success and activities. When the literature is examined, it is observed that adventure therapy has been investigated with many variables and its effectiveness has been proven with the existing programs. Social skills, social functionality, well-being, resilience, hope, self-esteem, self-confidence are some of them (Wick, 1996; Robertson, 1997; Kaly, 1999; Green, 2000; Peebles, 2006; Tucker, 2009; Stevens, 2009; Cale, 2010; BishowSemevolos, 2012; Christian, 2013).

On the other hand, cognitive flexibility which is a self-efficacy-related concept has been tested for effectiveness in the context of above-mentioned adventure therapy, is evaluated with various concept and aimed to increase by a few experimental researches. Intolerance of uncertainty is generally evaluated in terms of its relationship with clinical diagnoses, and it is observed that there is an indirect relation with hope and functionality in the protective 
sense. This is the intersection in terms of the unique relationship between adventure therapy, cognitive flexibility, and intolerance of uncertainty. In this study, it is aimed to increase the cognitive flexibility levels of candidate counselling psychologists and to reduce the intolerance of uncertainty levels by a group-based counselling approach.

\section{Methodology}

A pre-test-post-test experimental design was performed as a research design.In this $2 \mathrm{X} 2$ split plot pattern, the first factor shows experimental process groups (experimental-control) and the second factor shows repeated measures related to dependent variable (pre and post-tests) (Büyüköztürk, 2007).

In this study pre and post-test were applied to both groups and those two groups were compared following experiment process (Creswell, 2012). The programme developed within the scope of the research was applied to the pilot group consisting of 15 participants and applied to the experimental group following the necessary revisions and changes.

\section{Research Group}

The research group consisted of 12 candidate counselling psychologists who volunteered to participate in the study from Marmara University, Faculty of Education, Department of Guidance and Psychological Counselling. 25\% of the participants were male and the average age was 20.9, 11 of the participants stated that they have spent most of their lives in the city centre, and only 1 participant lived in the town. For all the participants, a group based on adventure therapy was a new experience they had never experienced a similar experience before.

The demographic data of experimental study group are shown in Table 1 and the demographic data of control group are given in Table 2.

Table1. Demographic Variables of the Research Group

\begin{tabular}{|llll|}
\hline Variable & Type & n & \% \\
\hline Sex & Woman & 9 & 75 \\
& Man & 3 & 25 \\
\hline Age & 20 & 1 & 8.3 \\
& 21 & 10 & 83.4 \\
& 22 & 1 & 8.3 \\
\hline $\begin{array}{l}\text { Place they spent their most of } \\
\text { the life }\end{array}$ & Town & 1 & 8.3 \\
& City & 11 & 91.7 \\
\hline Total & & & \\
\hline
\end{tabular}

Table2.Demographic Variables of Control Group

\begin{tabular}{|llll|}
\hline Variable & Type & $\mathbf{n}$ & $\mathbf{\%}$ \\
\hline Sex & Woman & 9 & 75 \\
& Man & 3 & 25 \\
\hline Age & 21 & 7 & 58.1 \\
& 22 & 1 & 8.3 \\
& 23 & 3 & 24.9 \\
& 28 & 1 & 8.3 \\
\hline $\begin{array}{l}\text { Place they spent their most of } \\
\text { the life }\end{array}$ & Town & 1 & 8.3 \\
& City & 11 & 91.7 \\
& & & \\
\hline Total & & $\mathbf{1 2}$ & $\mathbf{1 0 0}$ \\
\hline
\end{tabular}

\section{Data Collection Measurements}

The validity and reliability of the quantitative data were analysed using two scales previously tested within similar samples. The intolerance of uncertainty scale and inventory of cognitive flexibility were applied before and after treatment as pre and post-test measurements. Besides, in order to support quantitative data, a form developed by researchers was used to gain information about ideas of the participants related to the change they observed and how they feltthemselves after each session. 


\section{Cognitive Flexibility Inventory}

The Cognitive Flexibility Inventory (CFI) is a brief self-report measure developed by Dennis and Vander Wal (2010). CFI has a reliable two-factor structure, excellent internal consistency, and high 7-week test-retest reliability. This measure demonstrated good internal consistency and convergent validity with the Cognitive Flexibility Scale (martin \& Rubin, 1995).

Inventory consist of 20 items and scores range from 20 to 100; higher scores means higher cognitive flexibility. Inventory has two-dimensions; the first dimension is named as Alternatives $(1,3,5,6,8,10,12,13,14,16,18,19$, $20)$ and the second dimension is named as Control $(2,4,7,9,11,15,17)$.

The Turkish version of the scale was adapted by Gul and Dag in 2012. In the adaptation study, internal consistency coefficients of all inventory and alternatives and control subscales were calculated as $0.90,0.89$ and 0.85 , respectively. The Cronbach alpha value of the Alternatives subscale was found.91 and control subscale was found .84 (Dennis and Vander Wal, 2010).

\section{The Intolerance of Uncertainty Scale}

The original form of the scale was developed by Freeston in French and adapted into English by The Buhler and Dugas (2002). The purpose of the scale is to determine the emotional, cognitive and behavioural responses given to uncertain situations. The scale consists of 27 items and 4 factors. The internal consistency of the scale was .94 and the test-retest reliability was .74 (Buhr and Dugas, 2002). Subscales of the scale are; "Uncertainty is sad and stressful", "Uncertainty prevents action", "Uncertain events are negative and should be avoided", "Uncertainty is not fair". Turkish adaptation, validity and reliability study of the scale was conducted by Sari and Dağ (2009). In this scale, intolerance of uncertainty decreases with higher scores. According to the adaptation study, the internal consistency coefficient was found to be .93 and the test-retest reliability coefficient was .66. (Sari and Dağ, 2009).

\section{Adventure Therapy Based Group Counselling Programme}

Adventure therapy-based group counselling program is developed by researchers, aiming to reduce intolerance of uncertainty while increasing cognitive flexibility. In this sense, current programs in the literature on adventure therapy and adventure-based counselling have been examined (Green, 2000; D'Eloia, 2014; Shellman, 2009; Tessneer, 2014; Walsh, 2009; Nikkel, 2013; Hutson, 2013; Frishman, 2006; DeHard Richardson, 2009; Stevens, 2008; Mason, 2006; Grüring, 2007; Bishov-Semevolos, 2012; Miller, 2003; Kornelson, 1996; Ray, 2007; Christian, 2013; Kally, 1999; Pommier, 1994; Cale, 2010; Fenton, 2006; Tillotson, 2008; Furie, 2011; Woodruff, 2009; Norton, 2007; Wick, 1996; Walsh, 2009; Paxton, 1998; Albright, 2011; Zwart, 1988; Pann, 1999). The general objectives of each session of this program are given below on Table 3 .

\section{Table 3. General Aims of Each Session}

\begin{tabular}{|c|c|}
\hline Sessions & Aims \\
\hline 1. Session & Understanding of the concepts of cognitive flexibility and intolerance to uncertainty \\
\hline 2. Session & $\begin{array}{l}\text { Realisingown cognitive flexibility and intolerance to uncertainty and evaluate their effects } \\
\text { on life }\end{array}$ \\
\hline 3. Session & Developing action plans to increase cognitive flexibility and deal with uncertainty \\
\hline 4. Session & Developing action plans to increase cognitive flexibility and deal with uncertainty \\
\hline 5. Session & $\begin{array}{l}\text { Noticing the relationship between cognitive flexibility and intolerance of uncertainty and } \\
\text { their own counselling skills }\end{array}$ \\
\hline 6. Session & $\begin{array}{l}\text { Noticing the relationship between cognitive flexibility and intolerance of uncertainty and } \\
\text { their own counselling skills }\end{array}$ \\
\hline 7. Session & Developing an action plan to develop their own counselling skills. \\
\hline 8. Session & eveloping an action plan to develop their own counselling skills. \\
\hline
\end{tabular}

\section{Analysis of Qualitative Data}

Content analysis, which is a method provides repeatable and valid results; used as a useful guide to information, perspective, re-display of facts and action (Tavşancıl\& Aslan, 2001), was used to analyse the qualitative data obtained. Content analysis is also known as a method for examining documents (Krippendorff, 2004)has an inductive structure which a certain data sent to general codes or themes. Although, at the beginning, the data is divided into sections, the final goal is to reveal a large and unified image (Creswell, 2012). Within the scope of this research, first data were prepared, and analysis units were determined and then the coding scheme was developed. 
Since there is no similar research on the subject, codes are formed entirely from the data. Once the coding scheme has been tested on the sample, the entire text is encoded accordingly. Finally, themes are generated from the data encoded and presented as tables (Zhang \& Wildermuth, 2009).

In content analysis, credibility is related to the focus of the study, the participants and the approach used to collect data (Kizlltepe, 2017). The focus of this study is to evaluate adventure therapy-based group counselling experiences of the participants in detail. For this purpose, qualitative data was collected from the participants with detailed questions at the end of each session. Another critical point for achieving credibility is to choose the most appropriate meaningful unit.

While coding the qualitative data, the sentences were chosen as the coding unit in this study. Another aspect of reliability in content analysis is certainty. Failures may occur during data collection if data is too large or extended over a long period of time (Kizılkaya, 2017). Therefore, following each session, qualitative data were collected after the experience. Transferability in qualitative research is possible with a clear and detailed explanation of the findings (Yıldırım\&Şimşek, 2012). For this purpose, the qualitative analysis findings are given in detail with the expressions of the participants.

\section{Analysis of Quantitative Data}

The data obtained from the 'Cognitive Flexibility Inventory' and 'Intolerance of Uncertainty Scale' which were applied to both experimental and control groups before and after the implementation were evaluated by Mann Whitney U test. Wilcoxon Signed Sequence Number Test was applied to the post-test scores of both group in order to compare the pre-test and post-test data of the experiment and control group. Thus, the difference between the groups was tested. The findings of experimental application quantitative data are given below.

\section{Findings}

\section{Findings of Quantitative Data}

No significant difference was found between experiment and control groups' cognitive flexibility and intolerance of uncertainty levels before experimental application ( $\left.\mathrm{z}_{\text {C.F.I. }}-752 ; \mathrm{p}>0.5 ; \mathrm{z}_{\text {I.U. }}-1,618 ; \mathrm{p}>0.5\right)$ whereas there was a difference in favour of the experiment group observed following the experimental application ( $\mathrm{z}_{\text {C.F.I. }}-2,228 ; \mathrm{p}<0.5$; $\left.\mathrm{z}_{\text {I.U.S }}-2,166 ; \mathrm{p}<0.5\right)$. These findings indicate that the adventure therapy-based group application is effective on increasing cognitive flexibility and decreasing intolerance of uncertainty of participants.

Based on the findings of Wilcoxon Signed Sequences Test, which was applied for in-group comparison, there was a significant difference between the pre-test and post-test cognitive flexibility level of the experimental group in favour of the post-test $(\mathrm{z}=-2,395, \mathrm{p}<.05)$. Similarly, the analysis showed that there was a significant difference between intolerance of uncertainty levels of the experiment group pre-test and the post-test values in favour of the post-test $(\mathrm{z}=2,987, \mathrm{p}<.05)$. On the other hand, it is found that there were no significant difference on neither cognitive flexibility nor intolerance of uncertainty levels of control group the control group between pre and posttest levels ( $\left.\mathrm{z}_{\text {C.F.I. }}=-.980, \mathrm{p}>.05 ; \mathrm{z}_{\text {I.U.S }}=-, 078, \mathrm{p}>.05\right)$.

\section{Findings of Qualitative data}

Qualitative data were collected through the form developed by researchers to evaluate the participants' experiences at the end of each session. Participants were asked to rate each session in terms of the contribution to their levels of cognitive flexibility, intolerance of uncertainty, and counselling skills. They rated the change they experienced in relation to the nature, activity, participants, leader and connection with the daily life in a scale from 1 to 5 . These factors are elements of the adventure therapy that lead to change (Gillis, \& Milledgeville, 1992; Amesberger, 1994; Gass, 1995; Hans, 2000; Glass, \& Myers, 2001; Itin, 2001; Fletcher, \& Hinkle, 2002; Beringer, \& Martin, 2003; Jones, Lowe, Risler, 2004; Beringer, \& Martin, 2003; Newes\&Bandoroff, 2004; Stevens at al., 2004; Tucker, 2009; Stevens, 2009; Houston, Knabb, Welsh, Houskamp, \& Brokaw, 2010; Bishow-Semevolos, 2012; Hoag, Massey, Roberts, \& Logan, 2013). The arithmetical average of the answers of each participant to each question asked by the form is given in the graph below. 


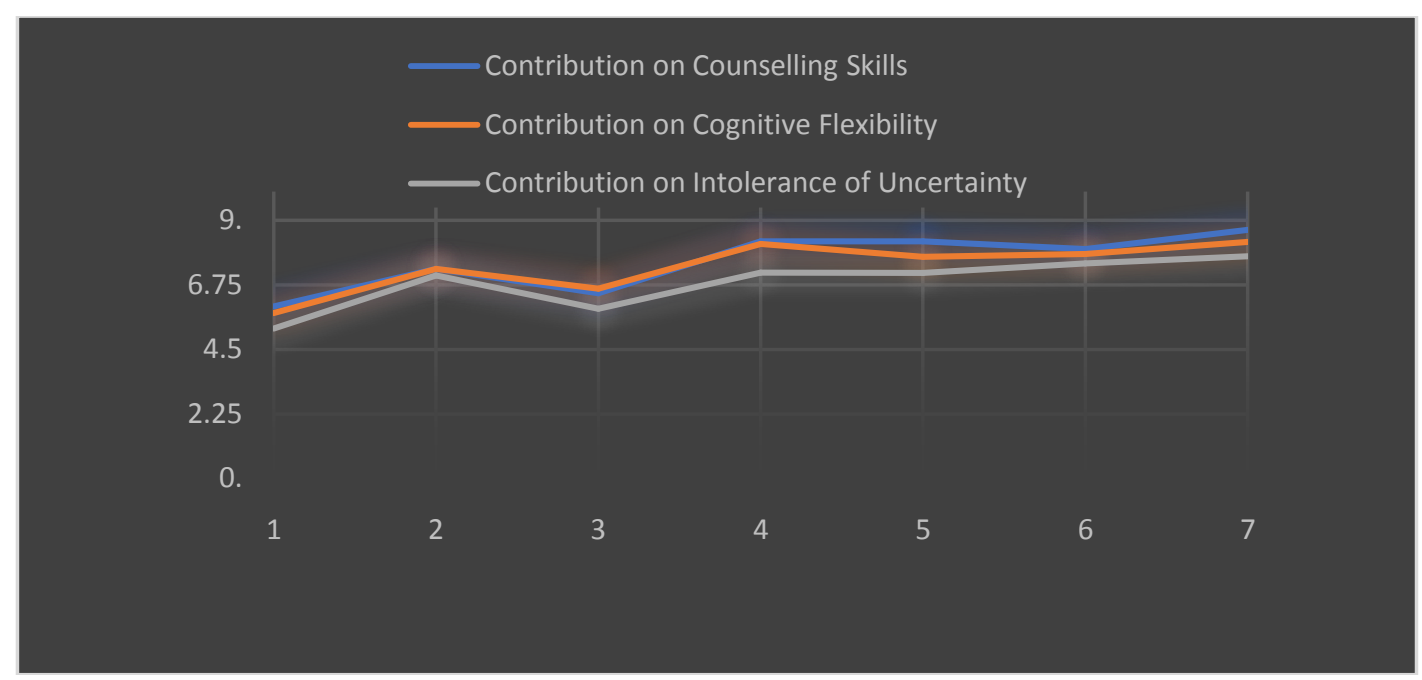

As seen in Graph 1, sessions provided a contribution to the participants' cognitive flexibility, intolerance of uncertainty and counselling skills, as well as it is observed that there is an increasing curve for each session.

It was noted that the first session contributed low while the contribution increased in the second session and has an upward trend since the $4^{\text {th }}$ session. On the other hand, the participants' responses to each of the three questions formed parallel curves on the basis of sessions.

As mentioned above, participants were asked to evaluate the level of contribution of nature, activity, participants, leader and daily life with each one of the scores from 1 to 5 , using each one of them only once.The arithmetic average of these evaluations is shown in the graph below.

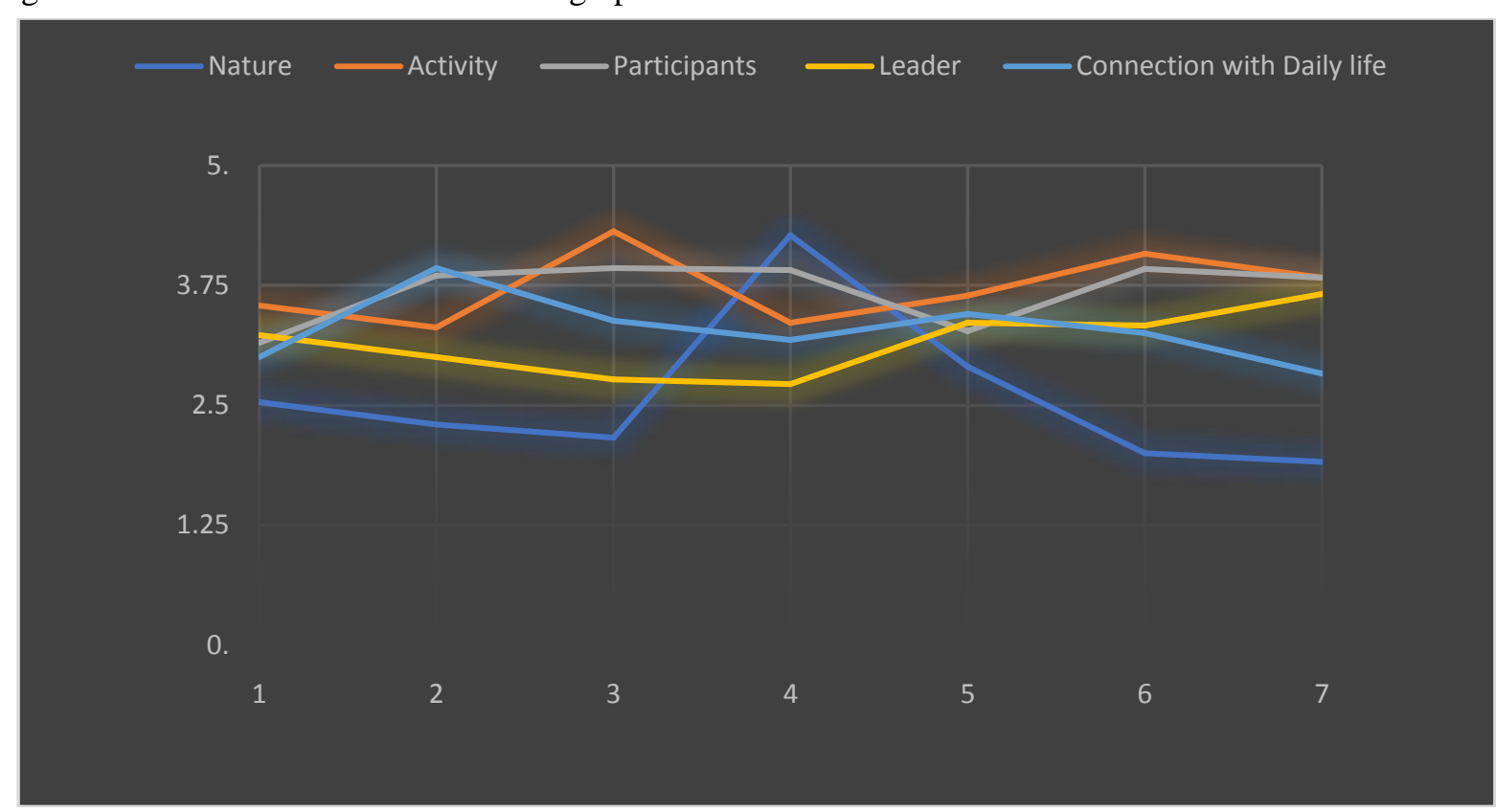

As seen in Graph 2, the activities were important in terms of the perceived change throughout the sessions. Leader and nature's impact on change has shown fluctuations. While the participants have a high level of influence in ensuring the change for each session, it is observed that the ability to connect with daily life also has a high level of impact despite fluctuations.

Additionally, participants were asked to evaluate the changes in the session by means of the forms given at the end of each session. Participants were asked about how the activities and sharing in the session mentioned contribute their counselling skills; how their experiences with nature affect themselves; if there was anything, they thought they would change in activities; what is the most influential thing during each session and finally how they feel themselves at the end of the session. Received answers were transferred to the computer and then analysed separately for each session. Table 4 for the summary of all sessions included themes is given below. 


\begin{tabular}{|c|c|c|c|c|}
\hline Sessions & $\begin{array}{l}\text { Contribution of the } \\
\text { session as a } \\
\text { counsellor }\end{array}$ & $\begin{array}{l}\text { Contribution of the } \\
\text { nature as a counsellor }\end{array}$ & $\begin{array}{l}\text { The most influential thing in the } \\
\text { session }\end{array}$ & Feelings \\
\hline $\begin{array}{l}\text { 1. } \\
\text { Session }\end{array}$ & $\begin{array}{l}\text { To be able to } \\
\text { comprehend the terms } \\
\text { cognitive flexibility and } \\
\text { intolerance of } \\
\text { uncertainty } \\
\text { Generating Alternatives } \\
\text { Creative (Flexible) } \\
\text { thinking }\end{array}$ & $\begin{array}{l}\text { Awareness of the } \\
\text { senses } \\
\text { Peace }\end{array}$ & $\begin{array}{l}\text { Dynamic of Group } \\
\text { Awareness }\end{array}$ & $\begin{array}{l}\text { Relaxed/Relieved } \\
\text { Happy } \\
\text { Curious } \\
\text { Had fun }\end{array}$ \\
\hline $\begin{array}{l}2 . \\
\text { Session }\end{array}$ & $\begin{array}{l}\text { Generating Alternatives, } \\
\text { Comprehending the } \\
\text { terms Cognitive } \\
\text { Flexibility and } \\
\text { Intolerance of } \\
\text { Uncertainty }\end{array}$ & $\begin{array}{l}\text { Linking Objects and } \\
\text { Events } \\
\text { Positive Impact of the } \\
\text { Nature } \\
\text { Keep Trying Until Get } \\
\text { a Solution } \\
\text { Effects of } \\
\text { Symbolisation }\end{array}$ & $\begin{array}{l}\text { Symbolisation/concretisation } \\
\text { Impacts of the communication on } \\
\text { People } \\
\text { The Relationship between } \\
\text { performance and the boundaries }\end{array}$ & $\begin{array}{l}\text { Happy-Good } \\
\text { Relieved } \\
\text { Awareness } \\
\text { Hopeful }\end{array}$ \\
\hline $\begin{array}{l}3 . \\
\text { Session }\end{array}$ & $\begin{array}{l}\text { Ability to Accomplish } \\
\text { Multiple Tasking } \\
\text { Collaboration }\end{array}$ & $\begin{array}{l}\text { Generating Alternative } \\
\text { Solutions } \\
\text { Positive Impact of the } \\
\text { Outdoor } \\
\text { Importance of Focusing } \\
\text { Multiple Things }\end{array}$ & $\begin{array}{l}\text { Multitasking } \\
\text { Connection with the life } \\
\text { Corporation }\end{array}$ & $\begin{array}{l}\text { Good } \\
\text { Happy } \\
\text { Hopeful }\end{array}$ \\
\hline $\begin{array}{l}4 . \\
\text { Session }\end{array}$ & $\begin{array}{l}\text { Creative (Fluent) } \\
\text { Thinking } \\
\text { Empathy } \\
\text { Impact of Concretisation } \\
\text { Analogy }\end{array}$ & $\begin{array}{l}\text { Using Metaphors - } \\
\text { Analogies } \\
\text { Different Solutions } \\
\text { Recovery Effect of the } \\
\text { Nature }\end{array}$ & $\begin{array}{l}\text { Connecting Depending on the context } \\
\text { Therapeutic Effect of the Nature } \\
\text { Multiple solution }\end{array}$ & $\begin{array}{l}\text { Peaceful } \\
\text { Happy } \\
\text { Good }\end{array}$ \\
\hline $\begin{array}{l}5 . \\
\text { Session }\end{array}$ & $\begin{array}{l}\text { Generating Alternatives, } \\
\text { Creative Thinking } \\
\text { Usage of Materials } \\
\text { /Techniques }\end{array}$ & $\begin{array}{l}\text { Finding Objects from } \\
\text { the Nature as a } \\
\text { Solution Tool } \\
\text { Impacts of Generating } \\
\text { Alternatives } \\
\text { Impacts of Analogies }\end{array}$ & $\begin{array}{l}\text { Generating Alternatives } \\
\text { Creative Thinking } \\
\text { Being a Group } \\
\text { Adapting to New Situation }\end{array}$ & $\begin{array}{l}\text { Good } \\
\text { Happy }\end{array}$ \\
\hline $\begin{array}{l}\text { 6. } \\
\text { Session }\end{array}$ & $\begin{array}{l}\text { Generating Alternatives, } \\
\text { Creative Thinking } \\
\text { (Fluency) } \\
\text { Importance of non- } \\
\text { verbal } \\
\text { CommunicationAwarene } \\
\text { ss of the Efforts to } \\
\text { Express Myself } \\
\text { Creative Thinking }\end{array}$ & $\begin{array}{l}\text { Multiple Thinking } \\
\text { Productivity } \\
\text { Flexible Thinking } \\
\text { Soothing Impact of the } \\
\text { Nature } \\
\text { Awareness }\end{array}$ & $\begin{array}{l}\text { Coping with the uncertainty } \\
\text { Impacts of the non-verbal } \\
\text { communication } \\
\text { Creativity }\end{array}$ & $\begin{array}{l}\text { Relieved } \\
\text { Flexible } \\
\text { Enjoying the Decision } \\
\text { Happy }\end{array}$ \\
\hline $\begin{array}{l}7 . \\
\text { Session }\end{array}$ & $\begin{array}{l}\text { Creating Alternatives, } \\
\text { Learning Different } \\
\text { Techniques } \\
\text { Development of the } \\
\text { Flexibility }\end{array}$ & $\begin{array}{l}\text { Positive Impact of the } \\
\text { Nature } \\
\text { The idea of having } \\
\text { counselling sessions in } \\
\text { nature } \\
\text { Contribution to the } \\
\text { Cognitive Flexibility } \\
\text { Comfort }\end{array}$ & $\begin{array}{l}\text { Multiple Solutions } \\
\text { Different viewpoint } \\
\text { Concretisation }\end{array}$ & $\begin{array}{l}\text { Relaxed } \\
\text { Happy }\end{array}$ \\
\hline
\end{tabular}

As seen above, based on the statements of the participants, the qualitative data obtained for each session and for each question were subjected to content analysis separately. The qualitative was first coded and the themes were obtained from these codes. The themes are consistent with the literature in terms of cognitive flexibility and intolerance of uncertainty, while incorporating elements of adventure therapy. In the discussion section below, the conclusions of all quantitative and qualitative findings are discussed with the findings of the literature. 


\section{Discussion}

When the literature is examined, it is observed that almost all the studies on the concept of cognitive flexibility are aimed at understanding the concept and associating it with other concepts. Conceptually, cognitive flexibility includes to generate alternative ideas and responding alternatively; to organize behaviours in accordance with changing situations; to deal effectively with new and difficult situations (Johnco, Wuthrich, \&Rapee, 2013; Altunkol, 2011; Stahl \& Pry, 2005; Crone, Ridderinkhof, Worm, Somsen\&Molen, 2004; Maltby, Day, McClutcheon, Martin \&Cayanus, 2004; Martin\&Anderson, 1998; Kloo, Parner, Aichorn\&Schimdhuber, 2010). The program developed for this research includes these kinds of activities that had not been experienced by the participants before. Throughout the programme participants were encouraged to develop alternative ideas specific to situations. Particularly in some activities, participants were asked to think about new patterns of behaviour that are suitable for varying situations. Participants described the adventure course, which was implemented at the end of the programme, as challenging for themselves but all participants acted different from their predictions on this course and managed to cope with this new and difficult situation. All these behaviours can be considered as behaviours that conform to the definition of cognitive flexibility mentioned above. On the other hand, it can be said that participants are faced with inexperienceable situations in a unique environment which is a nature of adventure therapy (Amesberger, 1994; Beringer, \& Martin, 2003; Newes, \&Bandoroff, 2004; Albright, 2011). All the tasks in this programme require an alternative and extraordinary thinking and coping style. This congruence between the nature of cognitive flexibility and adventure therapy may have provoked participants in terms of the development of cognitive flexibility.

There is a very little studies aimed at developing cognitive flexibility, either directly or indirectly. In the study conducted by Johnco, Wuthrich, and Rapee (2013), it was observed that those with low levels of cognitive flexibility were more incapacitated in cognitive restructuring. In this study, cognitive flexibility was measured as a tool for developing cognitive restructuring. In a similar study conducted with the participants with depression and anxiety symptoms, only a few of the participants showed changes in cognitive flexibility levels as a result of cognitive behavioural group therapy (Johnco, Wuthrich, \&Rapee, 2014). Another study conducted with 25 Buddhist meditators; participants were shown mindfulness exercises. After 6 weeks of meditation activity, a positive correlation was found between cognitive flexibility and meditation effectiveness. According to this study, it is observed that there is a close link between attention function of mindfulness and increase in cognitive flexibility. In this respect, it can be said that mindfulness is closely related to the increase of attention and cognitive flexibility (Moore \& Malinowski, 2009).

It is known that problem solving skill is one of the predictors of cognitive flexibility (Bilgin, 2009). Cognitive flexibility allows individuals using regulatory strategies for evaluation and it also necessary for creativity and problem solving (Kloo, Parner, Aichorn\&Schimdhuber, 2010). Thanks to the cognitive flexibility, individuals can perform with little experience in new tasks (Rougier, Noelle, Braver, Cohen \& O'Reilly, 2005);increase the potential for coping with internal and external stressors (Koesten, Schrodt\& Ford, 2009). On the other hand, during the adventure therapy process, participants are confronted with specific problem situations. While participants are expected to produce solutions to these problem situations at the activities, participants are also free to participate actively in events or to be an observer during the event (Schell, Cotton \&Luxmoore, 2010). In accordance with these findings, some aspects of the programme such as requiring problem solving at the tasks given may provoke the development of cognitive flexibility in participants.

According to researchers, individuals with high cognitive flexibility can be able to evaluate alternative ways in human relations and have higher success in adapting to social situations (Maltby, Day, McClutcheon, Martin \&Cayanus, 2004; Martin \& Anderson, 1998). Individuals with lower levels of flexibility are often referred to as strict and ritualists, and have difficulty adapting to new demands when activity or procedures change (Anderson, 2010). In this aspect, cognitive flexibility is a feature that is expected to be high in counselling psychologist. Study conducted by Passon and Oldsen (1969) with counsellors, relationship between cognitive flexibility and empathic sensitivity was investigated. Data were collected from 30 counselling students. It was found that cognitive flexibility was positively related to empathic sensitivity (Hill, 2008). In this study, participants' being candidate counselling psychologists may have motivated them to develop their cognitive flexibility.

According to another study, it was observed that the students with high cognitive flexibility asked to solve the problems with a different technique, solved problems more successfully (Star \& Seifert, 2006). Within the scope of this program, participants were asked to produce alternative solutions to problems in different contexts. This may be another aspect of the programme which have been effective in improving the cognitive flexibility levels of the participants.

Participants expressed sessions help them to apprehend the concept of cognitive flexibility and they gained awarenessrelated to this concept.

'It made me realize that there was a clear relationship between cognitive flexibility and intolerance of uncertainty (Participant 3, Session 1) 
'When I am confronted with an uncertain situation, I can make a contribution to the client by considering the alternatives more positively and flexibly.' (Participant 8 , Session 2)

Cognitive flexibility is defined as ability to switch between thoughts (Stevens, 2009; Crone, Ridderinkhof, Worm, Somsen, \& van der Molen, 2004), interaction of multiple mechanisms to respond to multiple demands (Ionescu, 2012; Barbey, Colom\& Grafman, 2013); ability to produce alternative solutions (Silver, Hughes, Bornstein $\&$ Beversdorf, 2004; Maria, 2006).

Bilgin (2009) defines cognitive flexibility as as awareness of individuals related to the options and their adaptation to the different and new situations as well as their competent feelings in those situations. In this sense it can be said that cognitive flexibility helps individuals to see the connections they have previously skip (Barbey, Colom \& Grafman, 2013). Following the sessions, participants developed insight into what cognitive flexibility means as a concept and how it relates to intolerance of uncertainty. Accordingly, they thought that they could approach their clients in a more flexible way by the help of thinking about alternatives.

Developmentally, cognitive flexibility begins to develop from childhood, peaking in adulthood and then following a U-shaped curve (Epsy, 1997; Martin \& Anderson, 1998; Blaye\&Bonthoux, 2001; Crone, Ridderinkhof, Worm, Somsen, \& van der Molen, 2004; Dick, 2005; Stahl \& Pry, 2005; Deak, 2009; Kloo, Parner, Aichorn\&Schimdhuber, 2010; Jacques \&Zelazo, 2010; Anderson, 2010; Dick, 2014). In this study, participants were in adulthood, where cognitive flexibility is the highest in developmental terms. Therefore, their developmental period may have made it easier for participants to become aware of their cognitive flexibility and to realize that this concept is started to develop for them. According to Martin \& Anderson (1998), cognitive flexibility means; an individual's awareness of communication alternatives;ability of regulation according to the situation; being flexible in self-efficacy. Therefore, cognitive flexibility is an important concept in terms of social relationships of individuals in daily life. This concept, as the most basic feature and definition of cognitive flexibility, is related to individuals' ability to evaluate alternative ways in human relations and to show higher success in adapting to social situations (Maltby at al., 2004; Martin \& Anderson, 1998). Participants stated that there is an improvement in the way they produce solutions regardless of how environmental conditions are. Individuals who are cognitively flexible believe that they will be successful in different communication environments. They believe that they can make the necessary changes to achieve the interaction goal (Martin \& Anderson, 1998).

In another perspective, cognitive flexibility means achieving multiple tasks at the same time; find a new solution to the problem; then change the solution strategy if it is necessary to do so and create a new information or tool (Leber, Turk-Bowne, \& Chun, 2008; Monsell, 2003). According to Stevens, (2009), cognitive flexibility is defined as the ability of adapting certain situations, the ability to move from one thought to another, or the ability to look at different problems with multifaceted strategies. Therefore, individuals with high levels of cognitive flexibility can cope with new and difficult situations and produce alternative thoughts and ideas (Altunkol, 2011). In this study, participants expressed that they realized that they could think multiply and alternatively after the sessions. They also stated that changes occurred in their viewpoints; they discovered and developed the multiple thinking ability within themselves. By opening new doors in this context, they have developed their own methods for more flexible thinking.

Individuals with high levels of cognitive flexibility can perform with little experience in new tasks (Rougier, Noelle, Braver, Cohen \& O'Reilly, 2005). This performance can be explained by the ability of making necessary adjustments thorough cognitive flexibility. In addition, individuals who are trying to cope with increasing stimuli can make the necessary adjustments and adjustments through cognitive flexibility (Crone, Ridderinkhof, Worm, Somsen\&Molen, 2004). Participants expressed that they can produce more solution proposals and perceive themselves as being in a position that is neither limited nor dependent on methods but can produce methods. According to Martin \& Anderson (1998) cognitive flexibility levels of people who are aware of situational factors and who need regulation or are likely to make possible behavioural adjustments are higher than those who see only one way to solve difficulties.

"It has contributed in terms of looking at events from different angles and creating alternatives." (Participant 6, Session 1)

"Activities led to multiple thinking." (Participant 3, Session 1)

Creativity is one of the predictors of cognitive flexibility (Çuhadaroğlu, 2013) on the other hand flexible thinking is known to be necessary for creativity (Kloo, Parner, Aichorn\&Schimdhuber, 2010). Individuals with a high level of cognitive flexibility can effectively deal with new situations and produce alternative ideas to overcome these situations (Altunkol, 2011; Stahl \& Pry, 2005). Similarly, participants in this study expressed that they were provoked for creative thinking during the sessions. Theycame to the conclusion that being intertwined with nature and inspiring by nature both contributed to their creative thinking. In addition to this, as candidate counselling psychologists, they also stated that they realized how creative thinking can contribute to themprofessionally.

"I think I'm forced to develop more creative and flexible thinking strategies." (Participant 1, Session 1) 
"Solving problems through analogy by associating the problems with nature has contributed more to the ways of trying new ways. I realized I could look more creative in this way. Even though we seem to be abstracted by nature, we still have the ability to turn our roots back and think more rationally and flexibly within that cycle." (Participant 7, Session 4)

"I see that a counsellor should be creative, open-minded, both in and out of the session." (Participant 9, Session 5) Cognitive flexibility, which can be defined as the ability of this century, can be observed in many different areas from art and science to problem solving in daily life (Barbey, Colom \& Grafman, 2013). Cognitive flexibility is an important feature helps mankind carry out complex tasks such as performing multiple tasks, writing novels, and finding solutions that can adapt to changing demands (Ionescu, 2012).The capacity to fulfil multiple tasks for today's modern person is becoming one of the most outstanding talents of the human mind (Leber, Turk-Brown \& Chun, 2008).

The ability to switch between multiple tasks is at the centre of flexible behaviour (Badre\& Wagner, 2006). Participants expressed that they realized the difficulty of doing two things at the same time (multitasking), but they started to develop this skill on themselves. Sessions included activities where participants were given instructions to perform more than one task at the same time. (Session 3). Participants, who realized that they were able to perform more than one task thanks to these activities, observed that they could cope better with this difficult situation.

"I think I have developed my skills to do multiple things at the same time." (Participant 6, Session 3).

"I can experience how difficult to do two things at the same time and it helped me to take steps to improve myself" (Participant 11, Session 3)

Adventure therapy has many elements which may facilitate the change process. Collaboration is one of the key elements of adventure therapy. The process includes various activities that require participants to work together in cooperation (Amesberger, 1994; Glass, \& Myers, 2001; Tucker, 2009; Bishow-Semevolos, 2012). On the other hand, cooperation is a process related to flexible thinking, as well. Flexible thinking individuals are better at cooperation; inviting others to play; social skills such as self-monitoring and positive assertiveness (Stevens, 2009). In this context, collaborating in events which is an essential element of adventure therapy, may also improve the participants' flexible thinking skills.

"I saw that we can produce more than one solution to a problem." (Session 3, Participant, 12)

"Collaborating, seeing that I was successful, seeing how I could apply it in my life have impressed me." (Session 3, Participant, 6)

"I was impressed by how my partner encouraged me when I felt bad about finding a solution." (Session 3, Participant 11)

Abstracting is another key essential component of adventure therapy. Basically, all activities are used for the abstracting of real-life conditions (Gass, 1995). The adventure in the process offers a concrete, action-based and experimental tool for therapy (Beringer, \& Martin, 2003). When evaluated in this context, it can be argued that the experiences expressed by the participants about the concretization are the output of the adventure therapy.

"My human condition, which is intertwined with nature, became more evident. It makes the solution easier to see in concrete terms that even the search for solutions from nature feels good." (Session 4, Participant 7).

"In terms of context, I realized that I could find many solutions to a problem, and in the eyes of the client, I could abstract the situation through context." (Session 4, Participant 4).

Similar to concretization, simulation has also attracted the attention of participants throughout the process. Simulation is a method used to create metaphors.In the sessions, participants were informed about the techniques of simulation and then included activities to simulate them.Participants stated that they gained positive experiences in terms of finding solutions with simulation and thinking differently.

"The analogies we used were very nice. It was fun to look at things from different angels, to evaluate the same topic in another contexts." (Session 4, Participant 12).

"It was important to produce solutions for a single context. Setting up metaphor is important in counselling. Finding similarities with the nature can be done in the sessions." (Session 4, Participant 10).

At the end of the sessions, the participants were asked how they felt.When their answers are examined, it can be said that they left with positive emotions after each session in general.One of the outstanding elements of adventure therapy is that participants are taking part in fun activities in an environment they did not experience before (Itin, 2001; Newes, \&Bandoroff, 2004).Adventure therapy offers participants a counselling experience which is unusually fun. These entertaining activities may have contributed to the development of positive moods of the participants and the increase cognitive flexibility.Besides, research findings suggest that cognitive flexibility of individuals is improved by stimulating cognitive flexibility by activating positive mood (Nijstad, De Dreu, Rietzschel, \& Baas, 2010).At the end of the sessions, the positive mood of the participants may help in terms of provoking and developing their cognitive flexibility. 
"I'm fine. The group process was enjoyable, entertaining and instructive. I think every session gives me more awareness." (Session 5, Participant 1)

"I'm very happy. I think the group, the activities, the process is very entertaining and instructive. At first moment, I thought what I'm going to do but now, we we're all doing very good things." (Session 6, Participant 8)

Research shows that connection with nature or nature itself has an impact on mental health and well-being. (Ulrich, 1979; Ulrich, 1984; Frumkin, 2001). In this study, all sessions were conducted outdoors.

"Intertwined with nature gives people peace." (Session 2, Participant 7)

Time spent in a new environment (rural area) allows clients to think about their old behaviours (Hoag, Massey, Roberts, \& Logan, 2013). According to Cohen (1993), counselling in nature; backyards, parks and rural areas become a stakeholder for change and development. During the program, participants stated that they had discovered some aspects they did not realize before, they had developed in many different fields and they started to think more flexible and creative than before.

Outdoors are often seen as a magical field in adventure therapy. There are no distractions and stimuli of the civilization; people can start working together on different subjects in which they avoid or struggle (Hoag, Massey, Roberts, \& Logan, 2013). On the other hand, experience with learning theory claims that learning develops even more when an individual is out of his/her comfort zone and in an incompatible situation (Newes, \&Bandoroff, 2004). Outdoors are a valuable component in the therapeutic process because it is the opposite of the client's city base outdoor has a healing feature thanks to naturalness (Beringer, \& Martin, 2003; Gillis, \& Milledgeville, 1992). In addition to these, being active; being in the outdoors fits perfectly with the holistic approach that combines body, mind, action and excitement (Amesberger, 1994). Participants often expressed the positive effect of being outdoors on themselves.

"I feel my mind clear because we get plenty of air." (Session 3, Participant 12)

"My human condition, which is intertwined with nature, has become even more evident. It makes the solution easier to see in concrete terms that even the search for solutions from nature feels good." (Session 4, Participant 6) Another important factor in adventure therapy is the group process. Group members should work together for success; other group members do not tolerate a member's inappropriate behaviour. The members of the group are confronted with unsuitable behaviour and the problem must be discussed before the group continues to be active (Jones, Lowe, Risler, 2004). Neill and Dias (2011) suggest that group process has a critic importance on the social support and harmony as well as individual development and it should be examined with future research.

"The idea of acting and being in group was wonderful." (Session 1, Participant 2)

"I was impressed by the fact that when we are together in the activities, we can think from a different and diverse approach and we can produce a faster solution." (Session 1, Participant 7)

Challenge by choices is a unique aspect of adventure therapy. This principle is at the centre of many adventure therapy programs, widely referring participants to self-selection and self-regulation (Priest \&Gass, 1997; Albright, 2011). Individuals discover the risk and challenge with the programmes decorated with the idea of "challenge by choices. This basic concept is related to encourage and support individuals to determine their level of participation in protecting the rights of the group and individuals. Each participant has the right to withdraw when they see that there is a tremendous risk to continue as a part of achieving elections (Albright, 2011). Since the risk or perceived risk is the essence of many rural programs, theoretically, clients should be open or inclined to change in this process (Houston, Knabb, Welsh, Houskamp, \& Brokaw, 2010).

"The adventure park has prompted me to try new things. You can share the same track with a small child, and you are going in the same route with different ways. You have the chance to get nutrition and inspiration from your friends just like in the life. When I crossed the tracks, I realized that I had lost my time and became almost like walking on the road." (Session 8, Participant 12)

In addition to the Intolerance of Uncertainty Scale, participants were also asked to assess the change related to intolerance of uncertainty with a scale from 1 to 10 , at the end of each session. According to the participants, their observations on the contribution of the sessions to their intolerance of uncertainty levels were observed between 1 and 10, on the average of 5.2 in the first session and up to 7.7 in the last session. The level of intolerance, which could be accepted as moderate at the first session, increased throughout the sessions, and was evaluated by the participants as 7.7 on the last session.

"I have learned that my cognitive flexibility will increase my tolerance for uncertainty." (Session 1, Participant 7) Intolerance of uncertainty may cause intense anxiety through the introduction of intrinsic representations of uncertain knowledge(Dugas, Hedeyati, Karavidas, Buhr, Francis, \& Phillips, 2005).Research shows that the relationship between intolerance of uncertainty and anxiety is observed in the normal sample with no clinical diagnosis (Kertz, Stevens, McHugh, \&Björgvinsson, 2015; Dugas, Gosselin, \& Ladouceur, 2001; Buhr, 2001). 
When uncertainty occurs in any positive or negative situation, it causes anxiety in individuals.The relationship between intolerance of uncertainty and worryhas been found to be stronger for positive and unpredictable positive situations than for positive and negative situations. However, there was no difference between the ambiguous and unpredictable positive conditions in terms of their predictions (Bryne, Hunt, \& Chang, 2015).In other words, the fact that the situation can be evaluated as uncertain, rather than positive or negative, may bringconcern. In this sense, the change on intolerance of uncertainty levels of candidate counselling psychologistsare important for their professional development.

In the therapy process, individuals are vigilant against the dangers of uncertain situations if they have low levels of uncertainty and focus on potential negative impacts and raise awareness of their problems. They may be able to resist due to the fact that they perceive this situation as dangerous (Leite, \& Kuiper, 2008). Furthermore, uncertainty existspsychotherapy. Individuals may be uncertain about many issues related to themselves, they may not know what they need to change.In addition, they do not know how to change; what they learn about themselves as they do not know in the therapy process (Leite, \& Kuiper, 2008).

"Talking about the uncertainties that may arise in counselling has enabled us to see the possibilities more clearly." (Session 1, Participant 7)

"When I am confronted with an uncertain situation, I can make a contribution to the client by considering the alternatives more positively and flexibly and considering different alternatives." (Session 3, Participant 3)

People with high intolerance of uncertainty levels find all these conditions uncomfortable (Koerner, \& Dugas, 2007). Individuals who can tolerate uncertainty can struggle in the process of confronting problems involving uncertainty, they are less sensitive to the uncertainty in the confrontation process, and they are less stimulated against danger (Leite, \& Kuiper, 2008). As a result, individuals who can tolerate uncertainty may lead to less attention to ambiguous information, perceive fewer threatening experiences, and show a state of hyperarousal (Bardeen, Fergus, \& Wu, 2013). High levels of intolerance, low level of concern, and increased daily distress indicate high levels of uncertainty compared to those who show low levels of uncertainty (Zlomke, \& Jeter, 2014). According to the results of experimental research conducted with patients with generalized anxiety and panic disorder in order to increase the level of intolerance, it was observed that there was a significant and reliable decrease in the level of intolerance after 16 weeks of intervention (Boswell, Thompson-Hollands, Farchione, \& Barlow, 2013).

Similar to this study, a study conducted to change intolerance of uncertainty levels of the participants by physical activity. 30 minutes of aerobic exercise showed no effect on intolerance level (LeBouthiller\& Asmundson, 2015).

\section{Conclusion}

As a result, group-based adventure therapy has been a process in which candidate counselling psychologists increase their awareness of the concept of cognitive flexibility and intolerance of uncertainty; developed their cognitive flexibility, intolerance of uncertainty and creative counselling skills; and have a pleasant time.They realized the impact of nature in the process of change and thought to use some of the activities they experienced in the process in the future.

Adventure-based group counselling is a relatively new and exciting phenomenon in counselling field (Fletcher \& Hinkle, 2002). In this sense, this research makes a unique contribution to the literature in terms of using of adventure-based counselling to increase cognitive flexibility and decrease intolerance of uncertainty. Diversity of the data, which allows participants to express themselves and their experiences, is another strength of research. The research has some limitations. The most important of these is that the participants are volunteers. Random assignment is used to equalise differences that may arise from personal characteristics between groups (Creswell, 2012). In this study, since it was not possible to assign the participants to the groups randomly, the participation status of the volunteer members was taken into consideration while the experimental and control groups were formed. The experiment and control groups were found to be identical in terms of the mentioned variables. However, within the scope of the research, there are some limitations such as maturation and selection, which threaten internal validity due to unselected assignment to groups (Creswell, 2012). Another limitation of the research is that participants can be individuals ready for change in relation to volunteering. According to Creswell (2012) being selected is a threat that can affect the results in experimental research. Using the placebo control group could help to assess whether the result obtained will occur after any experimental application.

\section{Implications}

This program can be used in the field for the purpose of developing cognitive flexibility, intolerance of uncertainty and enhancing counselling skills of candidate counselling psychologists. Activities may be useful for candidate counselling psychologists to gain practical experiences, as well. Furthermore, activities can be used to improve the cognitive flexibility of individuals as an important concept in business life as well as in everyday life. 
Participants mentioned that they felt more competent and more confident as candidate counselling psychologists in the session evaluation forms.In order to evaluate this situation, it may be useful to collect longitudinal data. After becoming a counselling psychologist and seeing the clientsactively, data on the long-term effectiveness of the program can be collected by asking them what kind of effects they have on their experience as a student.

Cognitive flexibility can also be measured by different techniques such as neurological observations and card sequencing tests. The effectiveness of the program on the levels of cognitive flexibility of the participants can be evaluated in different ways using these techniques.

Adventure therapy-based group counselling is very effective when working with children and adolescents especially thanks to its 'consuming pleasant time' element. Especially the researches carried out with this age group are primarily needed.

Uncertainty is inevitable for individuals in the world where many big problems such as economic crises, natural disasters and terror are experienced.Research in the non-clinical sample should be done in relation to the concept of intolerance of uncertainty that everyone inevitably faces in everyday life.

\section{References}

Altunkol, F. (2011).

Üniversiteöğrencilerininbilişselesneklikleriilealgılananstresdüzeyleriarasındakiilişkininincelenmesi . Unpublished Master Thesis,ÇukurovaUniversity, Social Sciences Enstitution, Adana.

Amesberger, G. (1994). Personlichkeitsentwicklung durch outdoor-aktivittiten? Untersuchung zur personlichkeitsentwicklung und pealitiitsbewtiltigung bei sozial benachteiligten [Personal development through outdoor-activities? Research on personal development and copying with social reality of disadvantaged persons] Frankfurt: Afra Verlag.

Anderson, P. (2010). Assessment and Development of Executive Function (EF) During Childhood. Child Neuropsychology, 8 (2), 71-82.

Badre, D. \& Wagner, A.D., 2006. Computational and neurobiological mechanisms underlying cognitive flexibility. National Academy of Science, 103, 7186-7191.

Barbey, A. K., Colom, R. \& Grafman, J. (2013). Architecture of Cognitive Flexibility Revealed by Lesion Mapping. Neurolmage, 82, 547-554.

Bardeen, J. R., Fergus, T. A. \& Wu, K. D. (2013). The Interactive Effect of Worry and Intolerance of Uncertainty on Posttraumatic Stress Symptoms. Cognitive Therapy Research, 37, 742-751.

Beringer, A. \& Martin, P. (2003). On Adventure Therapy and The Natural Worlds: Respecting Nature's Healing. Journal of Adventure Education and Outdoor Learning, 3 (1), 29-40.

Bilgin. M. (2009). Developing a cognitive flexibility scale: Validity and reliability studies. Social Behavior and Personality, 37(3), 343-354.

Bilgin. M. ( 2009b). Bilişselesnekliğiyordayanbazıdeğişkenler. ÇukurovaÜniversitesiEğitimFakültesiDergisi, 36 (3), 142-157.

Bishow-Semevolos, J. (2012). Combining Art Therapy and Adventure Based counseling. Unpublished Master Thesis, Hofstra University.

Blaschke, S. (2017).The role of nature in cancer patients' lives: a systematic review and qualitative meta-synthesis. BMC Cancer. 25;17(1):370. doi: 10.1186/s12885-017-3366-6.

Blaye, A., \&Bonthoux, F. (2001). Thematic and taxonomic relations in pre-schoolers: the development of flexibility in categorization choices. British Journal of Developmental Psychology, 19, 395-412.

Boswell, J. F., Thompson-Hollands, J., Farchione, T. J. \& Barlow, D. H. (2013). Intolerance of Uncertainty: A Common Factor in the Treatment of Emotional Disorders. Journal of Clinical Psychology, 69 (869), 630645. DOI: $10.1002 /$ jclp.21965

Bowen, D. J., \& Neill, J. T. (2013). A meta-analysis of adventure therapy outcomes and moderators. The Open Psychology Journal, 6, 28-53. doi:10.2174/1874350120130802001

Bryne, S. B., Hunt, C. J. \& Chang, B. I. (2015). Comparing the Roles of Ambiguity and Unpredictability in Intolerance of Uncertainty. Behaviour Change, 32 (1), 26-34.

Buhr, K., \& Dugas M. J. (2002). The intolerance of uncertainty scale: psychometric \& properties of the English version. Behaviour Research and Therapy, 40 (8), 931-945.

Buhr, K. E. M. (2001). Examination of the Relationship between Intolerance of Uncertainty and Worry. Unpublished Master Thesis, Concordia University, Canada

Büyüköztürk, Ş. (2007). SosyalBilimlerịçinVeriAnalizi El kitabı. (8. Baskı). Ankara: PegemYayıncılık

Cale, C. (2010). A Case Study Examining the Impact of Adventure Based Counseling on High School Adolescent Self Esteem, Empathy, and Racism. Unpublished Doctoral Dissertation, University of South Florida, USA. 
Cason, D., \& Gillis, H. L. (1994). A meta-analysis of outdoor adventure programming with adolescents. Journal of Experiential Education, 17, 40-47.

Christian, D. D. (2013). Adventure Based Counseling: Exploring the Impact of ABC on Adaptive Functioning in High School Males. Unpublished Doctoral Dissertation, University of North Texas, USA.

Cohen, M. J. (1993). Counselling with nature: Catalysing sensory moments that let earth nurture. Counselling Psychology Quarterly, $6($ !), 39-52.

Creswell, J. W. (2012). Educational Research. (Fourth Ed.). Boston: Pearson Education Inc.

Crone, E. A., Ridderinkhof, K. R., Worm, M., Somsen, R. J. M. \& van der Molen, M. W. (2004). Switching Between Spatial Stimulus-Response Mappings: A Developmental Study of Cognitive Flexibility. Developmental Science, 7 (4), 443-455.

Çuhadaroğlu, A. (2013). BilişselEsnekliğinYordayıcıları. Cumhuriyet International Journal of Education, 2 (1), 86102.

D’Eolia, G. M. (2014). Adventure Therapy to Promote Resilience Among Adolescent Foster Youth: A Grant Proposal. Unpublished Master Thesis, California State University, USA

Deak, G. O. (2009). Problem Solving: Preschool Children Use Changing Verbal Cues to Infer Multiple Word Meanings. Journal of Cognition and Development, 1 (2), 157-191.

Dehart Richardson, E. (1998). Adventure-Based Therapy and Self-Efficacy Theory: Test of a Treatment Model for Late Adolescents with Depressive Symptomatology. Unpublished Doctoral Dissertation, Virginia State University, USA.

Dennis, P.D. ve Vander Wal, J.S. (2010). The Cognitive Flexibility Inventory: Instrument Development and Estimates of Reliability and Validity. Cognitive Therapy and Research, 34(3), 241-253

Dick, A. S. (2005). The Development of Cognitive Flexibility. Unpublished Doctoral Dissertation, Temple University, USA.

Dick, A. S. (2014). The Development of Cognitive Flexibility Beyond the Preschool Period: An Investigation Using a Modified Flexible Item Selection Task. Journal of Experimental Child Psychology, 125, 13-34.

Dugas, M. J., Gosselin, P. \& Ladouceur, R. (2001). Intolerance of Uncertainty and Worry: Investigating Specify in a Nonclinical Sample. Cognitive Therapy and Research, 25 (5), 551-558.

Epsy, K. A. (1997). The Shape School: Assessing executive function in preschool children. Developmental Neuropsychology, 13, 495-499.

Fenton, L. (2006). Adventure Education and Csikszentmihalyi's Flow Theory: A Critical Analysis of Stress and Optimal Experience as Learning Tools. Unpublished Master Thesis. Prescott College, Canada.

Fletcher, T. B. \& Hinkle, S. J. (2002). Adventure Based Counseling: An Inovation in Counseling. Journal of Counseling\& Development, 80, 277-276.

Frishman, J. S. (2006). The Adventure-Journey Perspective: Postmodern Adventure Therapy Expressed Through the Hero's Journey Metaphor. Unpublished Doctoral Dissertation, Massachusetts School of Professional Psychology, USA.

Fruie, J. (2011). Adventure Based Counseling As an Intervention For Bullying. Unpublished Doctoral Thesis, Alliant International University, USA

Gass, M. A. (1995). Adventure Family Therapy: An Innovative Approach Answering the Question of Lasting Change with Adjudicated Youth? Monograph on Youth in the 1990s, 4, 103-116.

Gass, M.A., Gillis, H.L., \& Russell, K.C. (2012). Adventure therapy: Theory, research, and practice. Routledge

Gillis, H. L., \& Speelman, E. (2008). Are challenge (ropes) courses an effective tool? A meta- analysis. Journal of Experiential Education, 31, 111-135.

Gillis, H. L. \&Mcleod, J. A. (1992). Successful Indoor Adventure Activities for Threating Substance Abuse with Adjudicated Adolescents and Incarcerated Adults. In Hanna, G. M, (Ed.) Celebrating Our Tradition Charting Our Future: Proceedings of the International Conference of the Association for Experiential Education (20th, Banff, Alberta, Canada, October 9-11, 1992

Glass, J. S., \& Myers, J. E. (2001). Combining the old and the new to help adolescents: Individual psychology and adventure based counseling. Journal of Mental Health Counseling, 23 (2), 101-114.

Green, G. T. (2000). The Effect of An Outdoor Recreation Program on the Resilience of Low Income, Minority Youth. Unpublished Doctoral Dissertation, The University of Georgia, USA

Grüring, C. (2007). The Role of Adventure Therapy in the Comprehensive Treatment of Adolescents Who Committed Sexual Abuse: A Case Study. Unpublished Master Thesis. Prescott College, USA

Gülüm, İ. V. ve Dağ, İ. (2012). TekrarlayıcıDüşünmeÖlçeği ve bilişselEsneklikEnvanterininTürkçeyeUyarlanması,Geçerliği ve Güvenirliği.

Anatolian Journal of Psychiatry, 13, 216-223.

Hans, T. A. (2000). A Meta-Analysis of the Effects of Adventure Programming on Locus of Control. Journal of Contemporary Psychotherapy, 30 (1), 33-60.

Hattie, J., Marsh, H., Niell, J., \& Richards, G. (1997). Adventure education and Outward Bound: Out of class experiences that make a lasting difference. Review of Educational Research, 67, 43-87. 
Hill, A. (2008). Predictors of Relationship Satisfaction: The Link Between Cognitive Flexibility, Compassionate Love and Level of Differentiation. Unpublished Doctoral Dissertation, Alliant International University, Los Angeles, USA.

Hoag, M. J., Massey, K. E., Roberts, S. D. \& Logan, P. (2013). Efficacy of Wilderness Therapy for Young Adults: A Firs Look. Residential Treatment for Children \& Youth, 30, 294-305.

Houston, P. D., Knabb, J. J., Welsh, R. K., Houskamp, B. M. \& Brokaw, D. (2010). Wilderness Therapy as a Specialized Competency. International Journal of Psychological Studies, 2 (2), 52-66

Hutson, L. A. (2013). Evaluation of an Urban Adventure Therapy Program for At-Risk Youth. Unpublished Doctoral Dissertation. The Chicago School of Professional Psychology, USA

Ionescu, T. (2012). Exploring the Nature of Cognitive Flexibility. New Ideas in Psychology, 30, 190-200

Itin, C. \& Mitten, D. (2006). The Nature and Meaning of Adventure Therapy in the International Context. Connecting with the Essence, Proceedings From the 4th International Adventure Therapy Conference (4IATC), February 1-4 Rotorua, Aotearoa, New Zeeland.

Itin, C. M. (2001). Adventure Therapy-Critical Questions. The Journal of Experiential Education, 24 (2), 80-84.

Jacobs, E. \& Schimmel, C.J. (2013a) Impact therapy: The courage to counsel. Impact Therapy Associates, WV.

Jacques, S., \&Zelazo, P.D. (2005). On the possible roots of cognitive flexibility. In B. D. Homer \& C. S. TamisLemonda (Eds.). The development of social understanding and communication (pp. 53-81). Mahwah, NJ: Lawrence Erlbaum.

Johnco, C., Wuthrich, V. M. \& Rapee, R. M. (2014): The Influence of Cognitive Flexibility on Treatment Outcome and Cognitive Restructuring Skill Acquisition During Cognitive Behavioural Treatment for Anxiety and Depression in Older Adults: Results of a Pilot Study. Behavior Research and Therapy, 57, 55-64.

Johnco, C., Wuthrich, V. M., \& Rapee, R. M. (2013). The role of cognitive flexibility in cognitive restructuring skill acquisition among older adults. Journal of Anxiety Disorders, 27, 576-584.

Jones, C. D., Lowe, L. A., Risler, E. A. (2004). The Effectiveness of Wilderness Adventure Therapy Programs for Young People Involved in the Juvenile Justice System. Residential Treatment for Children \& Youth, 22 (2), 53-67

Kaly, P. (1999). Examining the Effects of a Ship-Based Adventure Program on Adolescen Self-Esteem and EgoIdentity Development. Unpublished Doctoral Dissertation. University of Florida, USA.

Kertz, S. J., Stevens, K. T., McHugh, R. K. \&Björgvinsson, T. (2015). Distress Intolerance and Worry: the Mediating Role of Cognitive Variables. Anxiety, Stress \& Coping, 28 (4), 408-44.

Kızıltepe, Z. (2017). İçerikAnalizi. F. N. Seggie\& Y. Bayyurt (Ed.). NitelAraştırmaYöntem, Teknik, Analiz ve Yaklaşımları. 2. Baskı. Ankara:AnıYayıncılık.

Kloo, D., Parner, J., Aichorn, M. \& Schmidhuber, N. (2010). Perspective Taking and Cognitive Flexibility in the Dimensional Change Card Sorting (DCCS) Task. Cognitive Development, 25, 208-217.

Koerner, N. \& Dugas, M. J. (2007). An Investigation of Appraisals in Individuals Vulnerable to Excessive Worry: The Role of Intolerance of Uncertainty. Cognitive Therapy Research, 32, 619-638.

Koesten, J., Schrodt, P. \& Ford, D. (2009). Cognitive Flexibility as a Mediator of Family Communication Environments and Young Adults' Well-Being. Health Communication, 24, 82-94.

Kornelson, A. F. (1998). A Qualitative Study of the Process an Outcomes oaAchoool-Based Adventure Education/Therapy Program. Unpublished Master Thesis, University of Alberta, Canada.

Krippendorf, K. (2004). Content Analysis. An Introduction of Its Methodology. California: Sage Publications.

Leber, A. B., Turk-Browne, N. S., \& Chun, M. M. (2008). Neural predictors of moment-to-moment fluctuations in cognitive flexibility. Proceedings of the National Academy of Sciences of the United States of America, $105,13592-13597$.

LeBouthiller, D. M. \& Asmundson, G. J. G. (2015). A Single Bout of Aerobic Exercise Reduces Anxiety SensitivityBut Not Intolerance of Uncertainty or Distress Tolerance: A Randomized Controlled Trial. Cognitive Behavioural Therapy, 44 (4), 252-263.

Leite, C. \& Kuiper, N. A. (2008). Client Uncertainty and the Process of Change in Psychotherapy: The Impact of Individual Differences in Self-concept Clarity and Intolerance of Uncertainty. Contemporary Psychotherapy, 38, 55-64.

Louv, R. (2005). Last Child in the Woods: Saving Our Children from Nature Deficit Disorder. Atlantic Books: London.

Maltby, J., Day, L., McCutcheon, L. E., Martin, M. M. \& Cayanus, J. L. (2004). Celebrity worship, cognitive flexibility and social complexity. Personality and Individual Differences, 37, 1475-1482.

Maria, M. (2006). The Possible Relationship of Cognitive Style Rigidity-Flexibility of Cognitive Control with Properties of Nervous System. Social and Behavioral Sciences, 82, 917-920.

Martin, M. \& Anderson, C. (1998). The cognitive flexibility scale: three validity studies. Communication Reports, 11, (1) 1-9.

Martin, M. M. \& Rubin, R. B. (1995). A new measure of cognitive flexibility. Psychological Reports, 76 (2), 623626. 
Matsuoka, R. H. (2010). Student performance and high school landscapes: Examining the links. Landscape and Urban Planning, 97, 273-282.

Miller, R. C. (2003). Adventure Therapy and the Stepfamily. Unpublished Doctoral Dissertation, Pepperdine University, USA.

Monsell, S. (2003). Task switching. Trends in Cognitive Sciences, 7, 134-140.

Moore, A. \& Malinowski, P. (2009). Mediation, Mindfulness and Cognitive Flexibility. Consciousness and Cognition, 18, 176-186.

Neill, J.T., \& Dias, K.L. (2001). Adventure education and resilience: The double-edged sword. Journal of Adventure Education and Outdoor Learning, 1, 35-42.

Newes, S. \&Bandroff, S. (2004). What is Adventure Therapy. (In: Coming of Age: The Evolving Field of Adventure Therapy. Association for Experiential Education: USA.

Nijstad, B. A., De Dreu, C. K. W., Rietzschel, E. F. \& Baas, M. (2010). The Dual Pathway to Creativity Model: Creative Ideation as a Function of Flexibility and Persistence. European Review of Social Psychology, 21, 34-77.

Nikkel, L. J. (2013). Adventure Therapy for Youth with Addictions in Residential Treatment: An Analysis of Program Processes and Proximate Outcomes. Unpublished Master Thesis, The University of Manitoba, Canada

Norton, C. L., Tucker, A., Russel, K. R., Bettman, J. E., Gass, M. A., Gillis, H. L. \& Behrens, E. (2014). Adventure Therapy with Youth. Journal of Experiential Education, 37 (1), 46-59.

Norton, C. L. (2007). Understanding the Impact of Wilderness Therapy on Adolescent Depression and Psychological Development. Unpublished Doctoral Dissertation. Loyola University Chicago, USA.

Pann, J. M. (1999). The Effects of an Adventure Education Intervention on Self-Concept and Verbal Academic Achievement in Inner-City Adolescents. Unpublished Doctoral Dissertation. University of Miami, USA.

Passons, W. and Olsen, L. (1969). Relationship of counselor characteristics and empathetic sensitivity. Journal of Counseling Psychology, 16 (5), 440-445.

Paxtoni T. D. (1998). Self-Efficacy and Outdoor Adventure Programs: A Quantitative and Qualitative Analyses. Unpublished Doctoral Thesis. The University of Minnesota, USA.

Peebles, L. M. (2006). Improving Self Efficacy in College Students: A Modified Adventure Therapy Program. Unpublished Doctoral Dissertation, University of North Texas, USA.

Pommier, J. H. (1994). Experiential Adventure Therapy Plus Family Training: Outward Bound School's Efficacy with Status Offenders. Unpublished Doctoral Dissertation. Texas A\&M University, USA.

Pretty, J., Peacock, J., Sellens, M. \& Griffin, M. (2005). The Mental and Psychical Outcomes of Green Exercise. International Journal of Environmental Health Research, 15/5, 319-337.

Priest, S., \& Gass, M. A. (1998). Effective leadership in adventure programming. Human Kinetics: Champaign, IL.

Ray, S. L. (2007). The Experiences of Adolescent Girls Participating in an Adventure Therapy Program: A Qualitative Study. Unpublished Doctoral Dissertation. Alliant International University, USA.

Richardson, E. A., \& Mitchell, R. (2010). Gender differences in relationships between urban green space and health in the United Kingdom. Social Science \& Medicine, 71/3, 568-575. doi:10.1016/j.socscimed.2010.04.015

Robertson, J. L. (1997). The Effects of An Adventure Education Problem Based Approach Program on Students 'Self-Esteem and Perceived Problem Solving Ability. Unpublished Master Thesis, McGill University, Canada.

Rogerson, M., Brown, D. K. \&Sandercock, G. (2015). A Comparison of Four Typical Green Exercise Environments and Prediction of Psychological Outcomes. Perspectives in Public Health, 136 (3), 171180.

Rougier, N. P., Noelle, D. C., Braver, T. S., Cohen, J. D., \& O'Reilly, R. C. (2005). Prefrontal cortex and flexible cognitive control: rules without symbols. Proceedings of the National Academy of Sciences of the United States of America, 102, 7338-7343.

Rutko, E. A. \& Gillespie, J. (2013). Where's the Wilderness in Wilderness Therapy? Journal of Experiential Education, 36 (3), 218-232.

Sarı, S. ve Dağ, Đ. (2009) Belirsizliğetahammülsüzlükölçeği, endişeileilgiliolumluinançlarölçeği ve endişeninsonuçlarıölçeğininTürkçe’yeuyarlanması, geçerliliği ve güvenilirliği. Anadolu PsikiyatriDergisi, $10,261-270$.

Schell, L., Cotton, S. \&Luxmore, M. (2012). Outdoor Adventure for Young People With A Mental Illness. Early Intervention in Psychiatry, 6, 407-414.

Schellman, A. (2009). Empowerment and Resilience: A Multi-Method Approach to Understanding Processes and Outcomes of Adventure Education Program Experiences. Unpublished Doctoral Dissertation, Indiana University, USA.

Silver, J. A., Hughes, J. D., Bornstein, R. A., \& Beversdorf, D. (2004). Effect of anxiolytics on cognitive flexibility in problem solving. Cognitive Behavioral Neurology, 17, 93-97. 
Stahl, L. \& Pry, E. (2005). Attentional Flexibility and Perseveration: Developmental Aspects in Young Children. Child Neuropsychology, 11, 175-189.

Star, J. R., \& Seifert, C. (2006). The development of flexibility in equation solving. Contemporary Educational Psychology, 31, 280-300.

Stevens, B., Kagan, S., Yamada, J., Epstein, I., Beamer, M., Bilodeau,M.\& Baruchel, S. (2004). Adventure Therapy for Adolescents with Cancer. Pediatric Blood Cancer, 43, 278-284.

Stevens, S. L. (2009). Adventure Therapy and Adolescent Mothers: A Pilot Study to examine Effects of a Summer Camp Program on Parenting Stress in Adolescent Mothers. Unpublished Master Thesis, Prescott College, USA.

Tavşancıl, E. \& Aslan, A. E. (2001). Sözel, Yazılı ve DiğerMateryalleriçinİçerikAnalizi ve UygulamaÖrnekleri . Epsilon Yayınevi İstanbul.

Tessneer, S. E. (2014). Life Inoculation: Examining the Relationship Between Adventure Education Components and Resilience in Summer Camp Experiences. Unpublished Master Thesis, East Carolina University, USA.

Tillotson, C. (2008). Adventure in Marriage: An Adventure Based Marriage Education Program for Conflicted Couples. Unpublished Doctoral Dissertation, Azusa Pacific University, USA.

Tucker, A. R. (2009). Adventure-Based Group Therapy to Promote Social Skills in Adolescents. Social Work with Groups, 32, 315-329.

Walsh, M. A. (2009). Wilderness Adventure Programming as an Intervention for Youth Offenders: Self-Efficacy, Resilience, and Hope for the Future. Unpublished Doctoral Dissertation. University of Minnesota, USA.

Wick, D. (1996). Improving Self Esteem of Elementary School Children With Adlerian Adventure Therapy. Unpublished Doctoral Dissertation. Our Lady of the Lake University, USA.

Wood, C., Pretty, A. C., Sandercock, G., Barton, J. (2013). A Randomised Control Trial of Physical Activity in a Perceived Environment on Self-Esteem and Mood in UK Adolescent. International Journal of Environment Health Research, 23/4, 311-320. doi: 10.1080/09603123.2012.733935

Wood, C., Sandercock, G., Barton, J. (2014).Interactions Between Physical Activity and the Environment to Improve Adolescent Self-Esteem: A Randomized Control Trial. International Journal of Environment and Health, 7,2, 144-155. DOI: 10.1504/IJENVH.2014.067359

Woodruff, S. K. L. (2009). The Impact of Short-Term Adventure Experiences on the Body Image of Women over Forty. Unpublished Master Thesis. Prescott College, USA.

Yıldırım, A. \& Şimşek, H. (2012). NitelAraştırmaYöntemleri. 6. Baskı. SeçkinYayınları: Ankara

Zhang, Y. \&Wildemuth, B. M. (2009). Qualitative analysis of content. In B. Wildemuth (Ed.), Applications of Social Research Methods to Questions in Information and Library Science (pp.308-319). Westport, CT: Libraries Unlimited.

Zlomke, K. R. \& Jeter, K. M. (2014). Stress and Worry: Examining Intolerance of Uncertainty's Moderating Effect. Anxiety, Stress \& Coping, 27 (2), 202-215.

Zwart, T. J. (1988). The Effects of a Wilderness/Adventure Program on the Self-Concept, Locus of Control Orientation, And Interpersonal Behavior of Delinquent Adolescents. Unpublished Doctoral Dissertation, Western MichiganUniversity, USA. 